\title{
Modeling the influence of water cement ratios and slump partially replace cement with iron slag and silica fumes on compressive strength on High strength concrete
}

\author{
Eluozo $\mathrm{SN}^{* 1}$ and Dimkpa $\mathrm{K}^{2}$ \\ ${ }^{1}$ Department of Civil Engineering, Gregory University Uturu (GUU), Nigeria \\ ${ }^{2}$ Department of Architecture, Faculty of Environmental Science, Rivers State University, Nigeria
}

*Corresponding author: Eluozo SN, Department of Civil Engineering, College of Engineering, Gregory University Uturu (GUU), Abia State of Nigeria, Nigeria

\begin{abstract}
The study define the behaviour of silica fumes and iron slag as partial replacement for cement, the study isto monitor the extend water cement ratios and workability of concrete can influence the growth rate of concrete strength, themodel grade of concrete were designedapplying partial replacement, thesewere adoptedin other to achieved the required target strength, such conditions were applied, but predominant influence were paramount goalthe study want to achieve, this carried outto determined the effect of these stated parameters in the study, modeling techniques were adopted, these concept includes modeling and simulating, these parameter applying this concept is to determine the extent of influence in the study it will also expressed various rate of effect on the growth rate of designed concrete grade, it is observed thatthe surface areaof concrete's increases, particularly with the addition of fine aggregates, thisalso implies that it has a high demand for water. The study considered these reactions and monitors the extent from the mixed design; the increased in water leads to a higher water-to-cement ratio. Thus monitoring the variation effect of water cement ratios and it workability's expressed the predominant influence and its variation that was observed on the study. The researchalso expressed high significant rates ofother parameters, this includesvariation ofthe addictive dosage, compaction of concrete, permeabilityand porosity at differentmodel concrete mix,the growth rate from the model concrete to generate the target strength observed initial inner, it remains in that conditiondue to it particle size that is finer than cement. it complement the fines modulus of concrete, thus provide a ball-bearing effect that improves thixotropic behaviour, this influence modify concrete viscosity, while slag expressed it significant on the model concrete as itreduced permeability, improved resistance to chemical attack. The study observed the influenced from these two addictive based on these stated effect on the strength development influenced by the influential parameters, the derived model simulation were compared with experimental values and both parameters expressed best fits correlation, Experts will definitely fine these tools as another conceptual technique in developing different concrete model with partial replacement of silica fumes, Iron Slag to attain any target strength of concrete design.
\end{abstract}

Keywords: Modeling; Silica fumes; Iron slag; Compressive and Cement

\section{Introduction}

Several researches has been carried out studies to monitor the use of some localized materials which includes iron slag waste tyre and Rice husk Ash as partial replacement of cement. There are numerous materials known to be concrete properties such as fine and coarse aggregates in strength development, these techniques are numerous in recent literatures [1-7], the techniques definitely has produced high percentage result, the use of waste tyre has established wonderful feasibility using gargantuan amounts from waste tyre in concrete products. There are materials such as the used of plastic waste, these material are product familiar to environmental issues that is contemporary around the globe Choi et al. [8], recent research were carried out to evaluate the influences of waste PET bottles aggregate on properties of concrete. The study has developed concept of applying waste tyre 
and bottles, it has reduced it by $2-6 \%$ of normal weight concrete. Marzouk et al. [9] carried out comprehensive research on the use of waste consumed plastic bottle, such materials are applied as partial replacement for sand; it was examined from the research carried out by monitoring and observed the density that was lowered when the PET aggregate exceeding $50 \%$ by volume of sand. Suganthy et al. [10] another investigation carried out shows the reduction in weight of concrete, while that of the plastic content experienced an increase Ode and Eluozo [11]. Marzouk [9] more so, studies were carried out to examined the decrease of compressive strength from plastic concrete; this techniques was applied on sand replaced with plastic. Al-Manasser and Dalal (1997) other studies was carried out by on the effect of plastic on concrete mix. The observation was that split tensile strength experienced reduction as the plastic content increased. Batayneh et al. [12] the expression was on split tensile strength and the flexural strength of concrete mix including slump on the replacement, it was observed that the plastic content went up. Numerous research and investigated the strengths of plastic concrete, as Batayneh et al. [12] mentioned that the integration of ground plastic on concrete had influence on its compressive strength [13,14]. Naik et al. [15] examined the influence from postconsumer waste plastic in concrete as a soft filer [16-20].

\section{Theoretical Background}

\section{Governing equation}

$$
\frac{d c}{d x}+A_{(x)} C_{d}+B_{(x)} C_{d}^{n}=0
$$

\section{Nomenclature}

$\begin{array}{lll}\mathrm{C}= & \text { Compressive strength } \\ \mathrm{A}_{(\mathrm{x})}= & \text { Porosity of concrete } \\ \mathrm{B}_{(\mathrm{x})}= & \text { Additive and Cementious materials } \\ \alpha_{1 \mathrm{x}}= & \text { Water Cement Ratio }\end{array}$

$\mathrm{x}=\quad$ Curing Age

Transform the above Bernoulli's Equation to a linear first order DE gives:

$$
\begin{array}{r}
\frac{d k}{d x}+(1-n) k=(1-n) B_{(x)} \\
\text { Let I.F }=\ell^{-}{ }^{\alpha x_{1 x}}
\end{array}
$$

Use I.F to Solve (2) above

Hence, the general Solution becomes:

$$
C_{d}^{1-n}=-\frac{B}{A}+C e^{-\alpha_{1} x}
$$

\section{Materials and Method}

Experimental Procedures: Test Compressive Strength of Concrete cubes and size of $150 \mathrm{~mm} \times 150 \mathrm{~mm} \times 150 \mathrm{~mm}$ were cast with and without copper slag. During casting, the cubes were mechanically vibrated using a table vibrator. After 24 hours, the specimens were demoulded and subjected to curing for 7 and 56 days and seven-day interval to 56 days in portable water. After curing, the specimens were tested for compressive strength using compression testing machine of $2000 \mathrm{KN}$ capacity. The maximum load at failure was taken.

The average compressive strength of concrete and mortar specimens was calculated by using the following equation 5.1 .

Compressive strength $(\mathrm{N} / \mathrm{mm} 2)$ = Ultimate compressive load

Area of cross section of specimen $\left(\mathrm{mm}^{2}\right)$

\section{Results and Discussion}

Table 1-7; Figures 1-7.

Table 1: Predictive and experimental values of compressive strength at different curing age.

\begin{tabular}{|c|c|c|}
\hline Curing Age & $\begin{array}{c}\text { Predictive Values compressive Strength variation [w/c and slump } \\
\mathbf{0 . 3 / 1 1 5 ]}\end{array}$ & $\begin{array}{c}\text { Experimental Values compressive Strength [w/c and } \\
\text { slump[0.3/115] }\end{array}$ \\
\hline 7 & 15.61843043 & 14.14 \\
\hline 14 & 31.23686087 & 28.28 \\
\hline 28 & 62.47372174 & 56.56 \\
\hline 35 & 78.09215217 & 70.7 \\
\hline 42 & 93.71058261 & 84.84 \\
\hline 49 & 109.329013 & 98.98 \\
\hline 56 & 124.9474435 & 113.12 \\
\hline
\end{tabular}

Table 2: Predictive and experimental values of compressive strength at different curing age.

\begin{tabular}{|c|c|c|}
\hline Curing Age & $\begin{array}{c}\text { Predictive Values compressive Strength variation }[\mathbf{w} / \mathbf{c}] \\
\text { and slump 0.32/120] }\end{array}$ & $\begin{array}{c}\text { Experimental Values compressive Strength [w/c and } \\
\text { slump[0.32/120] }\end{array}$ \\
\hline 7 & 14.540015 & 14.007 \\
\hline 14 & 29.08003 & 28.014 \\
\hline
\end{tabular}




\begin{tabular}{|l|c|c|}
\hline 28 & 58.16006 & 56.028 \\
\hline 35 & 72.700075 & 70.035 \\
\hline 42 & 87.24009 & 84.042 \\
\hline 49 & 101.780105 & 98.049 \\
\hline 56 & 116.32012 & 112.056 \\
\hline
\end{tabular}

Table 3: Predictive and experimental values of compressive strength at different curing age.

\begin{tabular}{|c|c|c|}
\hline Curing Age & $\begin{array}{c}\text { Predictive Values compressive Strength variation [w/c and slump } \\
\mathbf{0 . 3 4 / 1 2 5}]\end{array}$ & $\begin{array}{c}\text { Experimental Values compressive Strength [w/c and } \\
\text { slump[0.34/125] }\end{array}$ \\
\hline 7 & 13.5478728 & 11.71890997 \\
\hline 14 & 27.0957456 & 23.43781994 \\
\hline 28 & 54.1914912 & 46.87563989 \\
\hline 35 & 67.739364 & 58.59454986 \\
\hline 42 & 81.2872368 & 70.31345983 \\
\hline 49 & 94.8351096 & 82.0323698 \\
\hline 56 & 108.3829824 & 93.75127978 \\
\hline
\end{tabular}

Table 4: Predictive and experimental values of compressive strength at different curing age.

\begin{tabular}{|c|c|c|}
\hline Curing Age & $\begin{array}{c}\text { Predictive Values compressive Strength variation [w/c } \\
\text { and slump 0.36/130] }\end{array}$ & $\begin{array}{c}\text { Experimental Values compressive Strength [w/c and } \\
\text { slump[0.36/130] }\end{array}$ \\
\hline 7 & 12.63204923 & 11.298 \\
\hline 14 & 25.26409846 & 22.596 \\
\hline 28 & 50.52819692 & 45.192 \\
\hline 35 & 63.16024615 & 56.49 \\
\hline 42 & 75.79229538 & 67.788 \\
\hline 49 & 88.42434462 & 79.086 \\
\hline 56 & 101.0563938 & 90.384 \\
\hline
\end{tabular}

Table 5: Predictive and experimental values of compressive strength at different curing age.

\begin{tabular}{|c|c|c|}
\hline Curing Age & $\begin{array}{c}\text { Predictive Values compressive Strength variation [w/c and } \\
\text { slump [0.37/135] }\end{array}$ & $\begin{array}{c}\text { Experimental Values compressive Strength [w/c and } \\
\text { slump[0.37/110] }\end{array}$ \\
\hline 7 & 11.97413 & 11.2 \\
\hline 14 & 23.94826 & 22.4 \\
\hline 28 & 47.89652 & 44.8 \\
\hline 35 & 59.87065 & 56 \\
\hline 42 & 71.84478 & 67.2 \\
\hline 49 & 83.81891 & 78.4 \\
\hline 56 & 95.79304 & 89.6 \\
\hline
\end{tabular}

Table 6: Variation of predictive water cement ratios on compressive strength of concrete.

\begin{tabular}{|c|c|c|c|c|c|}
\hline $\begin{array}{c}\text { Variation of Predictive Water } \\
\text { Cement Ratios }\end{array}$ & $\mathbf{0 . 3}$ & $\mathbf{0 . 3 2}$ & $\mathbf{0 . 3 4}$ & $\mathbf{0 . 3 6}$ & $\mathbf{0 . 3 7}$ \\
\hline $7 \mathrm{fcu}$ & 15.61843043 & 14.540015 & 13.5478728 & 12.63204923 & 11.97413 \\
\hline $14 \mathrm{fcu}$ & 31.23686087 & 29.08003 & 27.0957456 & 25.26409846 & 23.94826 \\
\hline $28 \mathrm{fcu}$ & 62.47372174 & 58.16006 & 54.1914912 & 50.52819692 & 47.89652 \\
\hline $35 \mathrm{fcu}$ & 78.09215217 & 72.700075 & 67.739364 & 63.16024615 & 59.87065 \\
\hline $42 \mathrm{fcu}$ & 93.71058261 & 87.24009 & 81.2872368 & 75.79229538 & 71.84478 \\
\hline $49 \mathrm{fcu}$ & 109.329013 & 101.780105 & 94.8351096 & 88.42434462 & 83.81891 \\
\hline $56 \mathrm{fcu}$ & 124.9474435 & 116.32012 & 108.3829824 & 101.0563938 & 95.79304 \\
\hline
\end{tabular}

Citation: Eluozo SN, Dimkpa K. Modeling the influence of water cement ratios and slump partially replace cement with iron slag and silica fumes on compressive strength on High strength concrete. Tr Civil Eng \& Arch 4(1)- 2020. TCEIA.MS.ID.000178. D0I: 10.32474/ TCEIA.2020.04.000178. 
Table 7: Variation of experimental water cement ratios on compressive strength of concrete.

\begin{tabular}{|c|c|c|c|c|c|}
\hline $\begin{array}{c}\text { Variation of Experimental Water } \\
\text { Cement Ratios }\end{array}$ & $\mathbf{0 . 3}$ & $\mathbf{0 . 3 2}$ & $\mathbf{0 . 3 4}$ & $\mathbf{0 . 3 6}$ & $\mathbf{0 . 3 7}$ \\
\hline $7 \mathrm{fcu}$ & 14.14 & 14.007 & 11.71890997 & 11.298 & 11.2 \\
\hline $14 \mathrm{fcu}$ & 28.28 & 28.014 & 23.43781994 & 22.596 & 22.4 \\
\hline $28 \mathrm{fcu}$ & 56.56 & 56.028 & 46.87563989 & 45.192 & 44.8 \\
\hline $35 \mathrm{fcu}$ & 70.7 & 70.035 & 58.59454986 & 56.49 & 56 \\
\hline $42 \mathrm{fcu}$ & 84.84 & 84.042 & 70.31345983 & 67.788 & 67.2 \\
\hline $49 \mathrm{fcu}$ & 98.98 & 98.049 & 82.0323698 & 79.086 & 78.4 \\
\hline $56 \mathrm{fcu}$ & 113.12 & 112.056 & 93.75127978 & 90.384 & 89.6 \\
\hline
\end{tabular}

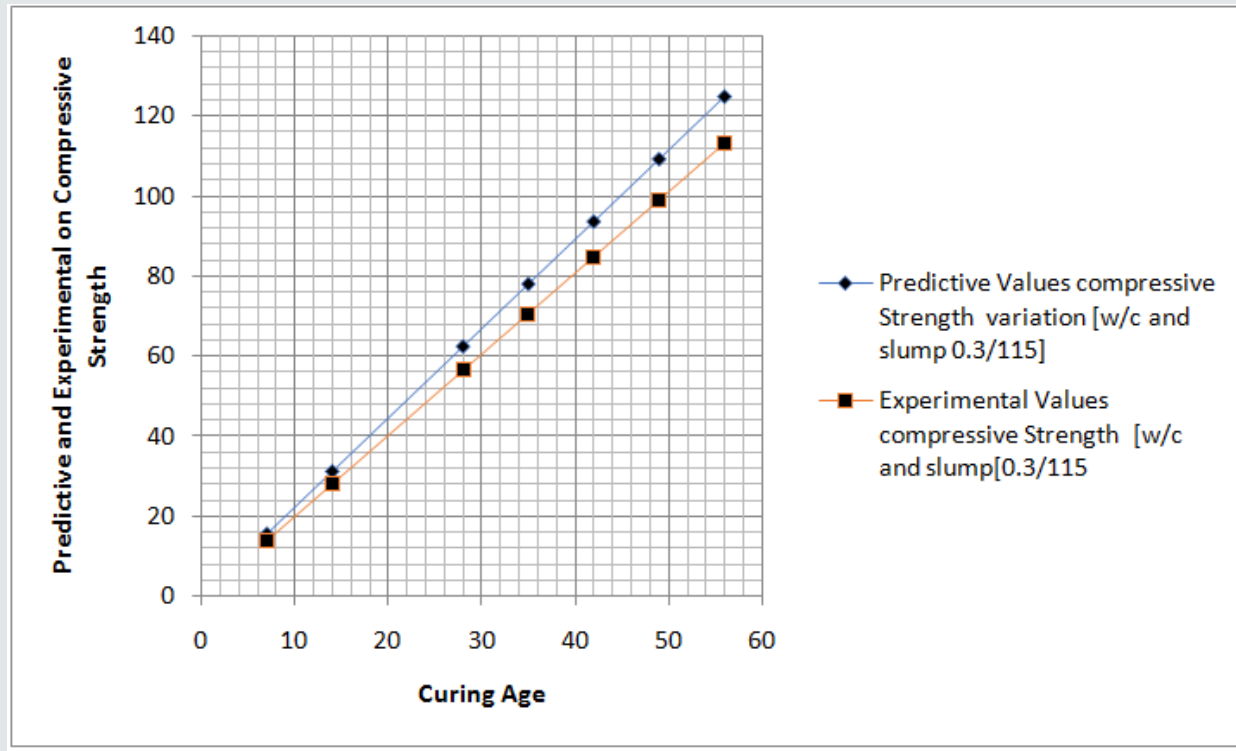

Figure 1: Predictive and experimental values of compressive strength at different curing age.

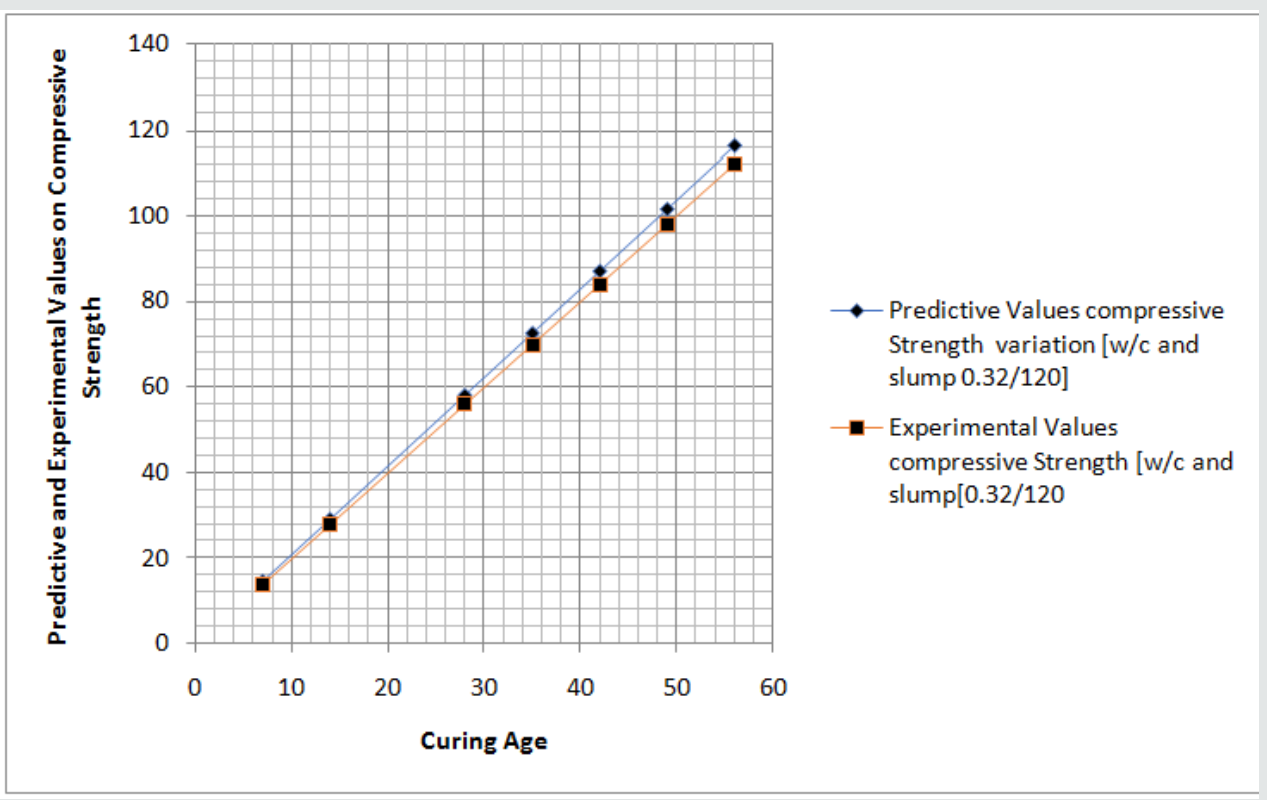

Figure 2: Predictive and experimental values of compressive strength at different curing age. 


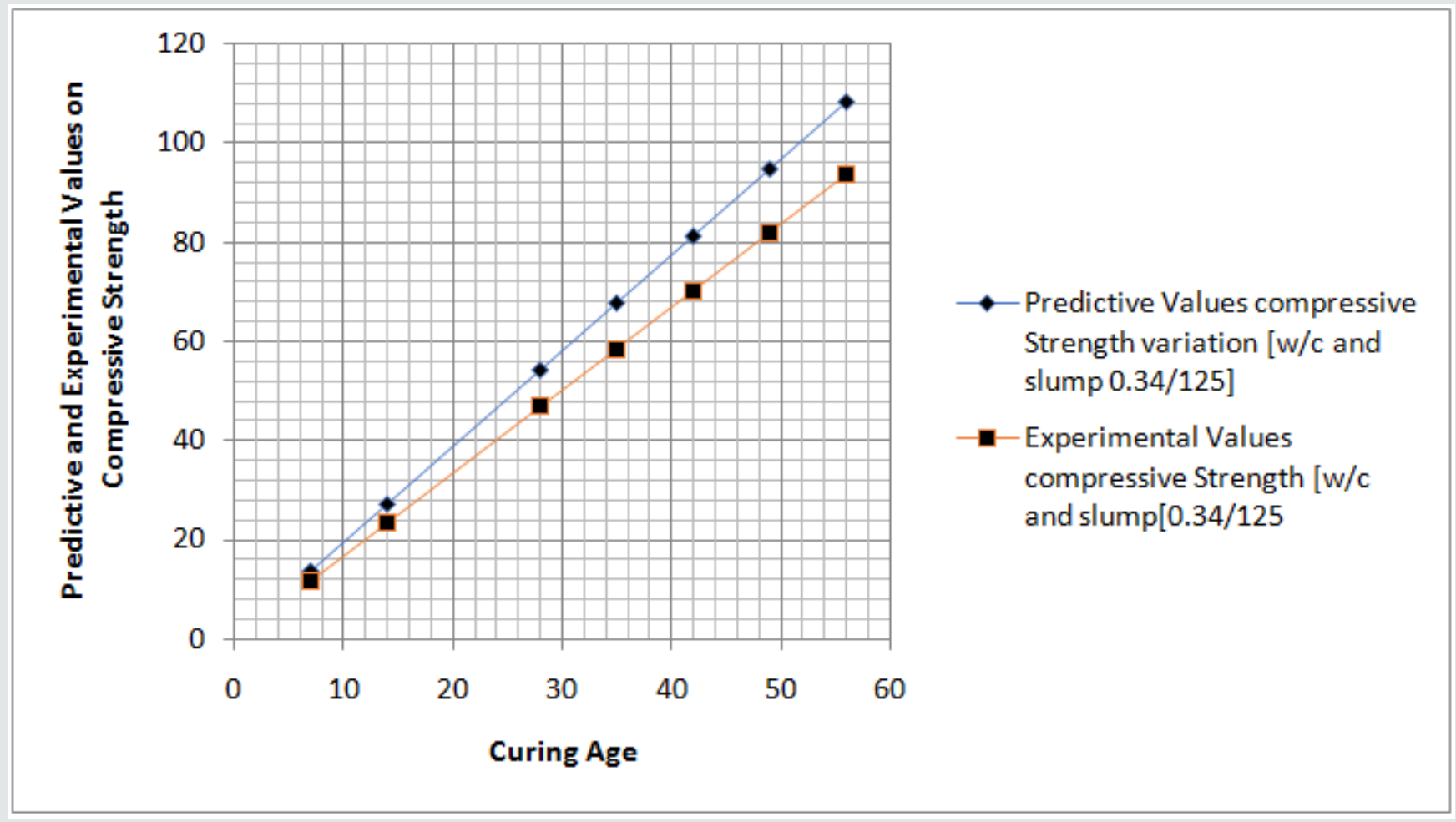

Figure 3: Predictive and experimental values of compressive strength at different curing age.

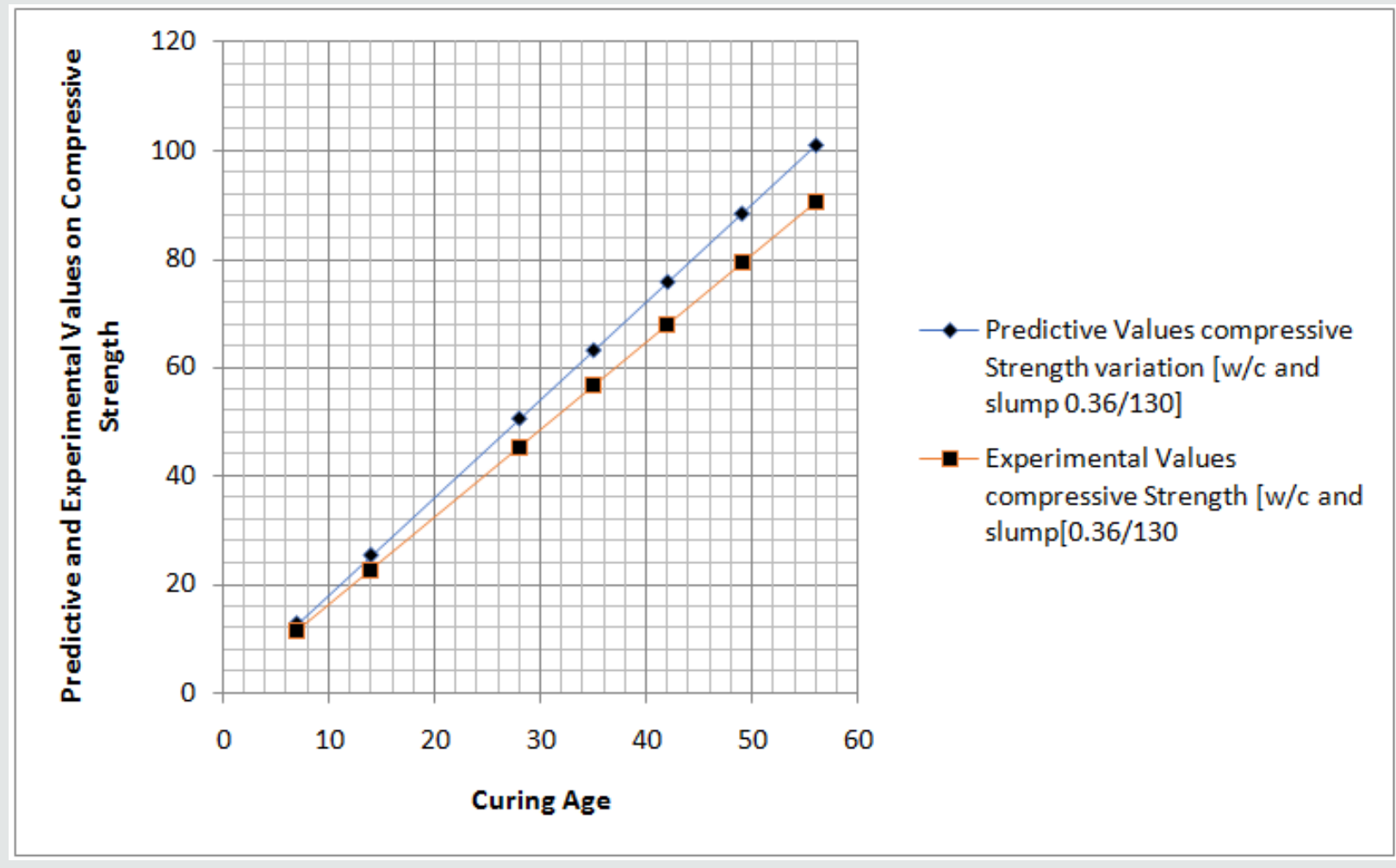

Figure 4: Predictive and experimental values of compressive strength at different curing age. 


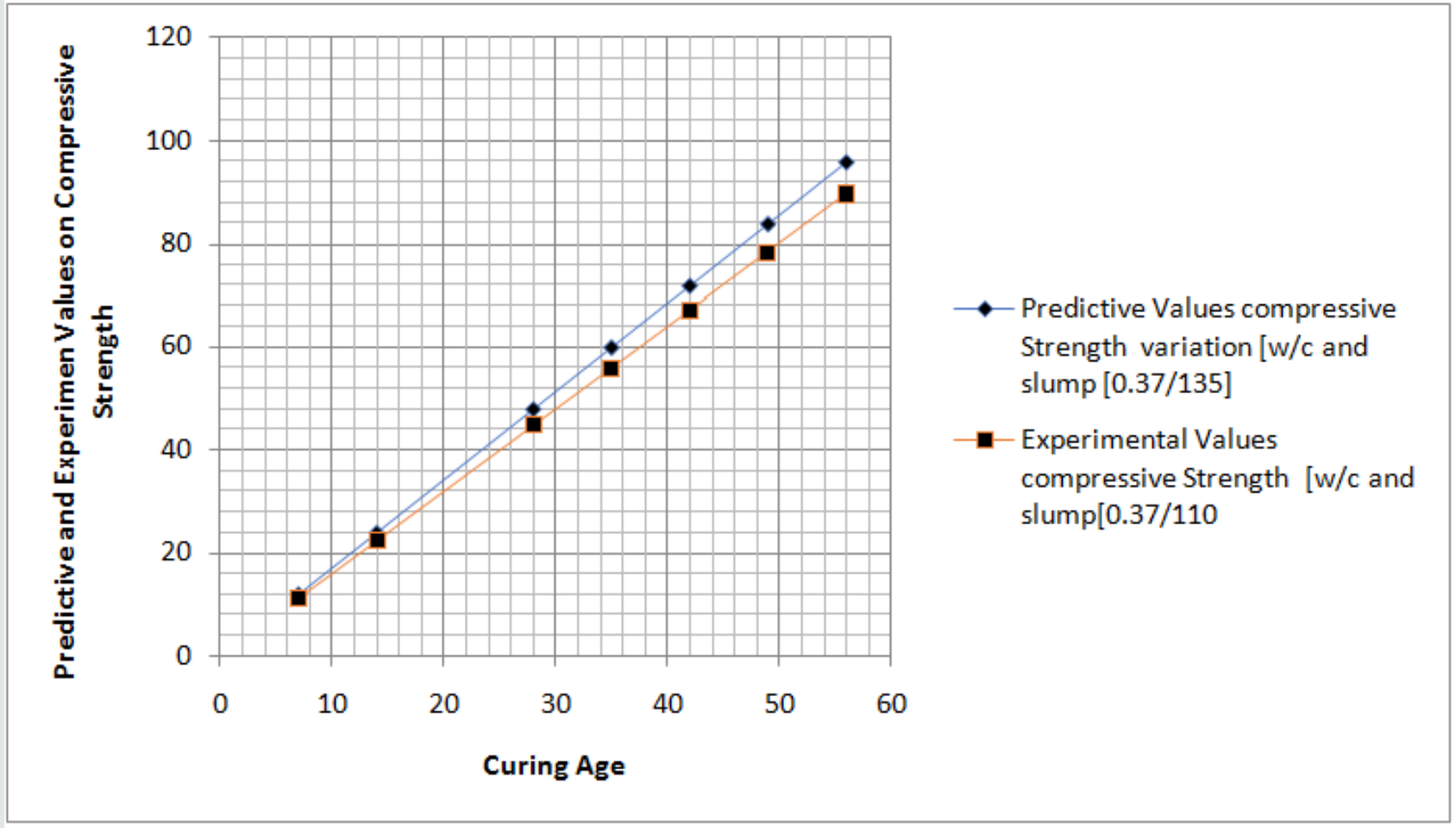

Figure 5: Predictive and experimental values of compressive strength at different curing age.

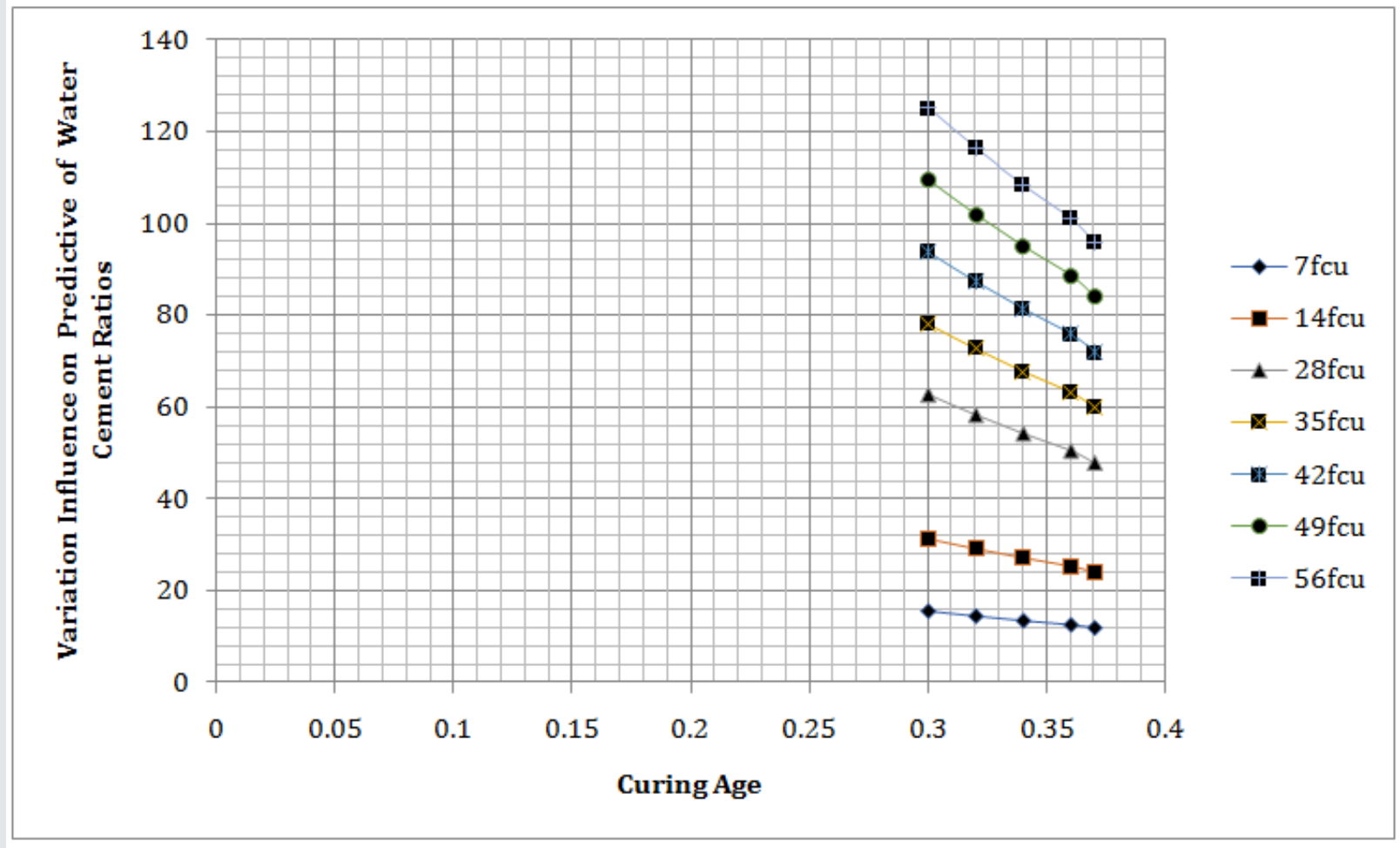

Figure 6: Variation of predictive water cement ratios on compressive strength of concrete. 


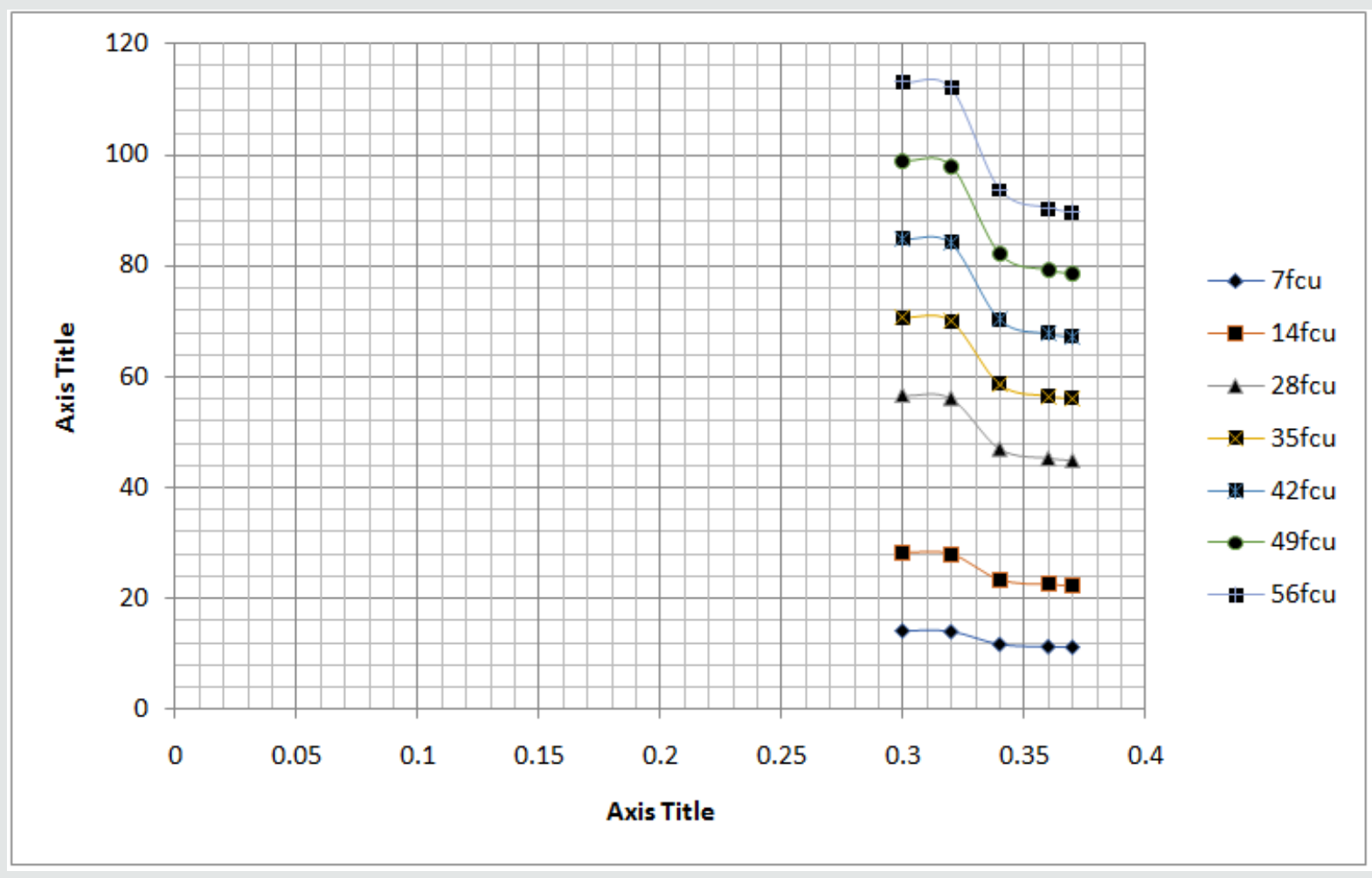

Figure 7: Variation of predictive water cement ratios on compressive strength of concrete.

The study explained the trend based on the concrete model applied in the mixed design, the reflection from figure one to seven, explained the trend in all the figures as it displayed linear growth were gradual increase were observed to the optimum values recorded at twenty fifty days of curing. but the reaction from all figures displayed linear increase in gradual process but with different compressive strength to the optimum level, the linear strength in all the figures that experienced different values are within seven and fifty six days, the predictive model thoroughly developed this variation, in different figures base on the water cement ratios and slump, similar condition were experienced on the experimental values, this were applied to validated the model, linear growth rate displayed predominantly based on the behaviour of silica fumes and iron slag, the research carried out explained the rate of concrete mixed designed proportion in all the figures, the research generated model that was applied by Silica fume and Iron Slag, the experimental values were applied at different mixed design within 7 and 56 days of curing, applying silica fumes and iron slag on the developed compressive strength of concrete. The research examined the developed concrete model that partially replaced cement with these two materials, the study predictive using these two modifiers Silica and Iron Slag similar to Parthi et al 2018 experimental values, the experimental values between 7 and 56 although Parthi 2018 curing days are within 7-28 days, these were in agreement but the study went further to examined other days that were not considered by Parthi et al 2018 with predictive parameters, these validated the simulation parameters, the dosage percentage for Silica fume and Iron Slag was at different percentage, the predictive simulation values at within two admixture observed the highest compressive strength generated from silica fumes and iron slag, the study examined the compressive strength from various admixtures by replacing cement with these two substance, at different water cement ratios, the influenced from different dosage of silica fumes and iron slag has expressed results within 7 and 56 days of curing age. More so, the simulation were able to monitor the effect from variation of slump and water cement ratios, other concrete characteristic that developed mechanical properties, this simulation generated variations influence from these parameters, it was observed that the system were affected by these variables and it was reflected on the growth rate of the compressive from different curing age.

\section{Conclusion}

The research work expressed the behaviour of the two modifiers on concrete strength that is applied within the two different admixtures, the variations of dosage and curing age were observed to determine the behaviour these material to an extent the study explained the growth rate of compressive strength with 
different water cement ratio, but with variation of these admixtures within 7 and 56 days of curing, while the dosage are at different percentage, but further study were carried out were increase in dosage and curing age was considered, others includes variation of slump on various rate of the mixed concrete workability's, the concept applied was modeling techniques, the study explained the behaviour of the concrete model by simulation to generate the predictive values, the behaviour of the materials generated various growth rate based on different factors, the predominant influential parameters such as variation of slump on concrete workability's and water cement ratios were able to expressed their various impact on concrete design. These techniques were observed to monitor other concrete characteristics that could influence the concrete model such as compaction, permeability, and porosities, this adopted applications were validated with experimental values, the study was also compared with study by Parthi et al 2018. The research were improved on the model concrete whereby the curing days were extended to fifty six days, this concept were integrated in the system, the predictive values further simulated the these other days that were not considered by Parthi et al 2018, the variation affected other days of curing that were not by Parthi et al 2018, this observation reflected growth rate of other days of curing that were not considered, the research developed best fits correlation between 7 and 56days, this development expressed the behaviour of the model partially replacement of cement with iron slag and silica fumes, influenced from slump and water cement ratios within 7 and 56 days of curing were comprehensively observed in the study, these strength development from predictive and experimental values was based on these factors, the slag played other influential roles as it serve as fillers within the void of the model concrete, the study is imperative because other curing time and its strength applying modeling has been developed, experts can applied this concept to monitor or predict other strength of this model grade of concrete for other constructions activities.

\section{References}

1. Topcu IB (1995) The properties of rubberized concrete. Cement and Concrete Research 25(2): 304-310.

2. Toutanji HA (1996) The use of rubber tyre particles in concrete to replace mineral aggregate. Cement and Concrete Composites 18(2): 135-139.

3. Khatib ZR, Bayomy FM (1999) Rubberized Portland Cement Concrete. ASCE Journal of Materials in Civil Engineering 11(3): 206-213.

4. Ling TC (2011) Prediction of density and compressive strength for rubberized concrete block. Construction and Building Materials 25(11): 4303-4306.
5. Ohemeng EA, Yalley PPK (2013) Models for predicting the density and compressive strength of rubberized concrete pavement blocks. Construction and Building Materials 47: 656-661.

6. Eric AO, Peter PY John D, Susan Dzifa D (2014) Utilization of waste low density polyethylene in high strengths concrete pavement blocks production. Civil and Environmental Research 6(5).

7. Ode T, Eluozo SN (2016) Predictive model on compressive strength of concrete made with locally $3 / 8$ gravel from different water cement ratios and curing age. International Journal of Scientific and Engineering Research 7(1): 1528-1551.

8. Choi YW, Moon DJ, Chung JS, Cho SK (2005) Effects of waste pet bottles aggregate on properties of concrete. Cement and Concrete Research 35(4): 776-781.

9. Marzouk OY, Dheilly RM, Queneudec M (2007) Volarisation of post-consumer waste in cementitious concrete composites. Waste Management 27(2): 310-318.

10. Suganthy P, Chandrasekar D, Kumar SPK (2013) Utilization of pulverized plastic in cement concrete as fine aggregate. International Journal of Research in Engineering and Technology 2(6): 1015-1019.

11. Ode T, Eluozo SN (2016) Model prediction to monitor the rate of water absorption of concrete pressured by variation of time and water cement ratios. International Journal of Scientific and Engineering Research 7(1): 1514-1527.

12. Batayneh M, Marie I, Asi I (2007) Use of selected waste materials in concrete mixes. Waste Management 27(12): 1870-1876.

13. Ode T, Eluozo SN (2016) Calibrating the density of concrete from washed and unwashed locally $3 / 8$ gravel material at various curing age. International Journal of Scientific and Engineering Research 7 (1): 15141552-15574.

14. Ode T, Eluozo SN (2016) Compressive strength calibration of washed and unwashed locally occurring $3 / 8$ gravel from various water cement ratios and curing age. International Journal Engineering and General Science 4(1): 462-483.

15. Naik TR, Singh SS, Huber CO, Brodersen BS (1996) Use of post-consumer waste plastics in cement-based composites. Cement and Concrete Research 26(10): 1489-1492.

16. Chaudhary AS Khan N, Kumar VP (2018) Analysis of concrete containing different admixtures as partial replacement of cement. Int. Journal of Engineering Research and Application 7(7): (Part-4) pp.31-38.

17. Ode T, Eluozo SN (2016) Predictive model to monitor variation of concrete density influenced by various grade from locally $3 / 8$ gravel at different curing time. International Journal Engineering and General Science 4(1): 502-522.

18. Ode T, Eluozo SN (2016) Predictive model to monitor vitiation of stressstrain relationship of $3 / 8$ gravel concrete with water cement ration [0.45] at different load. International Journal Engineering and General Science 4(1): 409-418.

19. Ode T (2004) Structural properties of Concrete made with locally occurring 3/8 gravel. M.TECH. Thesis Rivers State University of Science and Technology.

20. Ode T, Eluozo SN (2015) Predictive model to monitor the variation of concrete density influenced by various Grades from Locally $3 / 8$ gravel at different curing time. 


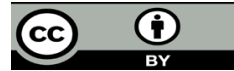

This work is licensed under Creative Commons Attribution 4.0 License

To Submit Your Article Click Here: Submit Article

DOI: 10.32474 /TCEIA.2020.04.000178

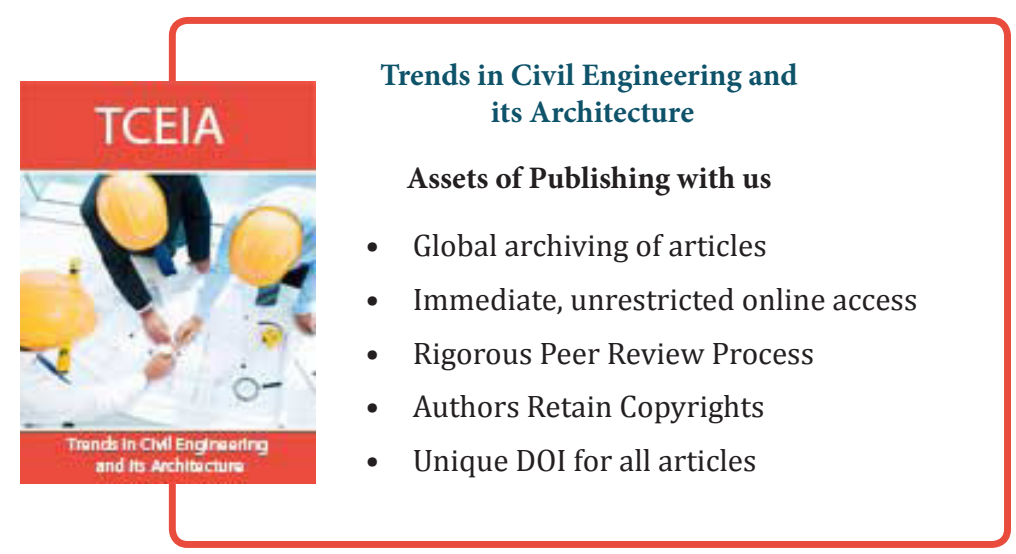

